\title{
Eclectic Considerations in the Communication Ideology of Salman Rushdie
}

\author{
Owoeye, Durojaiye Kehinde ${ }^{1, *}$ \\ ${ }^{1}$ Joseph Ayo Babalola University, Ikeji-Arakeji, Pmb, 5006 Ilesa, Osun State, Nigeria \\ *Correspondence: Joseph Ayo Babalola University, Ikeji-Arakeji, Pmb, 5006 Ilesa, Osun State, Nigeria \\ E-mail: duro_eye@yahoo.co.uk
}

Received: September 4, 2012 Accepted: December 3, 2012 Online Published: December 15, 2012

doi:10.5430/wjel.v2n4p76 URL: http://dx.doi.org/10.5430/wjel.v2n4p76

\begin{abstract}
Salman Rushdie's quest for a desirable and respectable postcolony takes an omnibus approach. In order to lift the postcolony out of the morass of colonial stranglehold, the all-inclusive stylistic means of theme, plot, characterization, setting, etc., are deployed to glorify indigenous values. Of these elements, the issue of language seems to be the most instructive as it is primary in the cultural denigration that follows colonial imposition of the foreign linguistic paradigm. Rushdie, consequent upon this, becomes clear-sighted about the need to deconstructively revise, in various ways, English language perspectives through some forms of indigenization and rule infractions. In addition, postcolonial fury is also not dispensed with in his wording. The present essay attempts to critique the degree of simplicity and complexity that accompanies the author's postcolonial language reordering ethos. Intermittent references to Ben Okri's works are to put in perspective how magical realist authors vary their stylistic media.
\end{abstract}

Keywords: Heteroglossia ; monoglossia; linguistic decolonization; linguistic culturalism; linguistic dissemination

\section{Introduction}

With the benefit of hindsight, the distance between the "host" and the "guest" begins to shrink in favour of the latter because it (the latter) understands that cultural pillars have to be breached for any attempt at subjugating the "natives" not to come unstuck. To this end, it (the "guest") goes straight for the cultural jugular: the language. Imposing the exogenous code on its hosts, and with an agreeing heterogeneous context, linguistic diversity its core, a gaping admittance into their mentality seems assured. Not a race to let go of a yawning opportunity, the white invaders exploit that advantage, consummating it with their superiority paradigms in all other areas of culture. The foregoing is a totality of the power equation that the colonizer considers to be a prefatory requisite to a successful adventurous campaign. The colonized, against that background, have learnt to conclude that an obstacle to wrenching power from the "centre" is "the real language problem: how to bend it, shape it, how to let it be our freedom, how to repossess its poisoned wells, how to master the river of words of time of blood"; consenting that without a successful intrusion into the ideals of language control, there will be "[...] no power base, no constituency" (Rushdie,1988: 281). Essentially, "mastery of language affords remarkable power" (Fanon, 1967: 18). Language use by Rushdie and Okri adequately puts this contention in proper perspective, especially "the energetic and innovative language of Rushdie's text[s], and particularly by his ability to enrich the English language with Indian accents" (Booker, 1999: 3). Keith Booker, quoting Maria Couto, is enthused by how

Rushdie uses phonemes and word patterns to suggest the vigour and liveliness of folk culture, the pace and variety of Indian life, the mythology of Bombay films, the brash exuberance of affluence, the violence simmering and on the boil .... His prose liberally sprinkled with Urdu, Hindi, and Sanskrit names, the deliberately uncontrolled flow of sentence with repetition and sonorous content, suggests the chant of Indian traditional texts. (Booker, 1999: 3/4)

Language, from this mythical structuring, is "the be-all and end-all behind which an emancipatory politics can best be glimpsed" (Banerjee, 2002: 123) bringing into the literary purview "the salience of the language metaphor, of 
questions of epistemology" (123). Jumpy, in The Satanic Verses, though envies and resents Hanif's control of their social locale, attributes it to the latter's omnivorous linguistic éclat, as "Hanif was in control of the languages that mattered: sociological, socialistic, blackradical, anti-anti-anti-racist, demagogic, oratorical, sermonic: the vocabularies of power" (Rushdie, 281). The victory of Hanif over Jumpy due to his recourse to linguistic syncretism to subdue his environment is being recuperated by Salman Rushdie in this novel in a bid to disorganize the colonizer's or realists' mono-linguistic sentiments. In any event, for the author, "language is courage: the ability to conceive a thought, to speak it, and by doing so to make it true" (281). Postcolonial writers have on that score endeavoured to, in their ideational and symbolic struggles, give authenticity to linguistic variegation; and considered realistically, they seem not far from the fact, for most postcolonial societies are multi-lingual, being multiracial.

Describing The Satanic Verses as a "clash of languages" (quoted in Booker, 1994: 248), Rushdie in particular sees language as the battlefront of antipodal forces, especially in respect of its use by absolutist regimes to rhetoricise their gullible subjects. For Rushdie, the

so-called Islamic "fundamentalism" does not spring, in Pakistan, from the people. It is imposed on them from above. Autocratic regimes find it useful to espouse the rhetoric of faith, because people respect their language, are reluctant to oppose it. This is how religions shore up dictators; by encircling them with words of power (quoted in Booker, 1994: 248).

Rushdie, in frowning at the opportunistic use of language by tyrants, may have concluded that "if language can be used in the interest of oppression, it can also be used to oppose that oppression" (Booker, 1994: 248). Muslim fanatics know this too well as he shreds the holiness in "Mahound", making him less of a respected member of the religious pantheon than his followers think:

Here's the point: Mahound did not notice the alterations. So there I was, actually writing the Book, or rewriting, anyway, polluting the word of God with my own profane language. But, good heavens, if my poor words could not be distinguished from the Revelation by God's own Messenger, then what did that mean? (quoted in Booker, 247)

By implication, Mahound, contrary to his believers, lacks the prophetic insight, or else he would have discerned Salman's autographic fraud. Essentially, Rushdie is deconstructing the entire architectonics of religion by affirming that God is a human invention, and that scriptures are literary texts.

Language use significantly empowers the continuity of the colonizer's domination of the postcolony, a truth postcolonial theorists do not dispute. The admission of the might of the linguistic shade of the neo-imperialist culture notwithstanding, the creative virtue that is inherent in postcolonial literature has helped in weakening this might. Rushdie, for instance, "is undoubtedly rooted in and works out of a Western literary tradition - that he writes in English is itself enough justification for this - yet, at the same time, he breaks away from that same tradition when he incorporates Eastern, or specifically Indian, tropes in his writing" (Sanga, 2001: 84). Disorganizing the structural base of the foreign code, transliteration, use of indigenous words and neologism are some of the methods that are deployed in this respect. Salman Rushdie's submission below is reflective of the literary counterstroke:

In order to allow different kinds of speech rhythms or different kinds of linguistic rhythms to occur in the book, I found I had to punctuate it in a very peculiar way, to destroy the natural rhythms of the English Language; I had to use dashes too much, keep exclaiming, putting in three dots, sometimes three dots followed by semi colons followed by three dashes [...] (Reder, 2000: 10)

This critical impression of part of the language making of Midnight's Children takes this critique into how Salman Rushdie takes advantage of the plasticity in language to disestablish "Euramerican" (Soyinka, 1993: 40) orthodox thoughts on phraseology. He is probably influenced to be radical to some degree by Mikhail Bakhtin's enquiry into the colonizer's strategy to aggregate different linguistic paradigms under a monoglossia. Bakhtin claims

that linguistics, stylistics and the philosophy of language had been major centralizing forces in the history of cultural formations whose method had consisted of seeking for unity in the face of diversity [through two means]; [first], the victory of one reigning language (dialect) over the others, the supplanting of languages, their enslavement, the process of illuminating them with the True Word, the incorporation of barbarians and lower social strata into a unitary 
language of culture and truth [...] [and second,] the centralization and solidification of grammatical or cultural forms and [...] cultural significance of such forms. (Cited in Hirschkop and Shepherd, 1994: 75)

Rushdie, like most postcolonial theorists, finds the style and language politicization policies unpalatable. Hence, his recourse to heteroglossia to create a departure from British hegemonic rule, leaning on "necessities of inclusion and patterns of exclusion" (Hirschkop and Shepherd, 1994: 75) to identify with normative standards of linguistic decolonization. Postcolonial writers' activist leaning is obviously invigorated by satire, and "when satire blends languages, styles, or discourses in its parodic mode or as a form of humorous incongruity, satire theories are inclined to set up linguistic gaps as hierarchical determinants of evaluation" (Ball, 2003: 23). Rushdie seems to glory in this blending as he gravitates towards "semantic gravitation" (Ball, 2003: 23) to make sure that " [...] extremes of high and low are merged" (Ball, 2003: 23) to reveal a sort of "radical dualism" (Ball, 2003: 23), an "“essential operational phenomenon" of satire" (Ball, 2003: 23).

The following discussion details the various ways through which Rushdie essays devitalizing, if creatively, the language might of neo-imperialism.

\section{Libertine Sentiments in Language Use}

The "fits and starts" language device, with its series of "prosodic jerks", which Rushdie says he takes from Desani's Haterr, definitely suits the illogicality that is indwelling in the magic world, where logic, reason and regularity are strangers. This disordered musical sequence - a form of poetic liberty - preponderates in the novel Midnight's Children. On the contrary, another form of poetic musicality controls the linguistic ideology in other postcolonial novelists' works. In most of Okri's works for instance, poetic prosody is marked by short sentences, with clear-cut punctuations to enhance fluency. Unlike Okri, Rushdie delights in neologisms, something he sees as fun, engendering playfulness out of manipulation of language, an aspect of his "“chutnification [sic]" of English or the creation of a hybrid language to de-colonize English" (Fletcher, 1994: 4). An Indian critic is not, however, amused in his appraisal of The Moor's Last Sigh, pouring critical strictures on Rushdie's string of concocted words like "killofy" (8), "wait-o" (88), "collectofy" (278) "stickofies" (12), "wreckofy" (263), "buttofy" (35), "thinkofy" (69), "tubbofy" (90), "dirtified" (125), "draggoes on" (141), "grew-o'ed" (146), (150), "catchoes" (150), "hate-o" (160), (125), "smellofying" (169), "bide-o" (8) "drowno" (226), "bumpo'ing” (226), "exceed-o" (124), "hookoed" (49), "come-latelies" (71), "yahoody" (88), "cathjew" (combination of Catholic and Jew) (104), "bleddy" (presumably for "bloody") $(166,167)$, etc.

The author, in The Satanic Verses, accessing philological liberation, damns conventional morphological rules, as he is wont to do, by merging words that normally have independent existence. He, in neological fashion, apprises the literati of the virility of words like "forsolong" (13), "sotospeak" (11), "almost-infinity" (3), "almost-dawn" (3), "downdown", "headfirst" (3), "suchmuch" (7) and "thenagain" (17) - all in a passion-induced urge to further his protest argument. Some instances of word duplication like "downdown" may have been used for the purpose of emphasis or intensity, making a statement about "Rushdie's agenda to expand the limits of the English language by inserting alternate vocabulary as well as a different context into the narrative" (Sanga, 63) thereby stressing "the regenerative nature of language; language not as a finite closed system, but rather an evolving process, constantly stretching and reshaping linguistic boundaries". (63) In part, Saussurean linguistic postulate of the arbitrariness of word formation towards being conventionalized is an intrinsic feature of Rushdean fiction.

Elements of the exoticizing of Indian-English, all the -fy and -o verb formations issue from female characters and underline various emotional states like anger, surprise, hate, envy and hardheartedness in which the personalities are, women being the nerve-centre of heroic projections in The Moor's Last Sigh. To C.J.S. Wallia, the critic in question, "it is too exotic to Indian ears" (www.indiastar.com/The Rushdie phenomenon), without minding its imaginative impact, especially on non-Indians, whose creative minds give admittance to such "unconventionality" in word formation, and also oblivious of the author's intention to "valorize the deviation from "standard English" as a sign of authenticity and a site of resistance" (Ball, 25). Rushdie's postcolonial fervour in language use would confound the British owners of English with the coining of the word "Britishers" (Rushdie, 2000: 106), a good example of making ordinary one's former "master", in Caliban-Prospero style.

Rushdie, raising the stakes of the novelistic newness that he longs for, goes beyond simple words as reeled out above. He delights in complex morphological creations - as James Joyce does in Ulysses - like "Gobbledygokhale", "Nallappaboomdiay" and "Karampalstiltskin" (Rushdie, 1994: 57). Aires, of the da Gama fold, uses these "nicknames" 
(57) to taunt the da Gama family staff when he assembles them to enquire about lost elephant items: "ivory tusks and Ganeshas" (57).

The first of the three words, "Gobbledygokhale", is a play on the sound made by a turkey, something like a belch, and "hale" to connote wholeness and heartiness, but in this context to condemn the wholeheartedness that is derived from criminality. It can also be suggestive of a voracious appetite for theft as implied in the word "Gobble". The second word, "Nallappaboomdiay", could be an indirect image of mass destruction that heist tendencies may cause. This mass destruction is probably projected through trifling with the word "Nallappaboomdiay" - a combination of "napalm" and "doomsday" - to suggest the possibility of a nuclear destruction of the world. The novelist creatively inverts "doom" and changes it to "boom" while retaining its apocalyptic thrust. He mocks at the idea of progress. The third word, "Karampalstiltskin", to start with, metaphorises the aggressiveness of a dog and terrorism, as the prefix "Karampal" seems to denote. Critiqued in the company of "stiltskin", larceny and horror are conjoined in those being accused of stealing ganeshas. Specifically examined, "stiltskin" is a reference to the accused as a family of robbers who vault over walls of houses to steal; the vaulting is aided by "stilts", with "kin" describing the staff's familial bond of negativity. These words remind one of Bakhtin's nuance of linguistic hybridity, which postulates that

a hybrid construction is an utterance that belongs, by its grammatical (syntactic) and compositional markers, to a single speaker, but that actually contains mixed within it two utterances, two speech manners, two styles, two "languages", two semantic and axiological belief systems ... There is no formal boundary between these utterances ... the division of voices and languages takes place within the limits of a single syntactic whole, often within the limits of a simple sentence. It frequently happens that even one and the same word will belong simultaneously to two languages, two belief systems that intersect in a hybrid construction - and, consequently, the word has two contradictory meanings, two accents (quoted in Sanga, 84),

a glittering example of "double-voice" or “double-accent" (Sanga, 84).

If those ones can be taken to be complex, the following may be understood in terms of compound-complex analysis: "Sneezysleepyhappydopeygrumpybashfuldoc" and "Sleepydopeygrumpybashful" (66). These long-strung words are in fact a psychoanalytic explication of a tipsy Snow White. She asks Camoens which of the "seven dwarfs" (referring to any in the string of words) he is. When he fails to respond, She undauntedly says "Not sneezy, not Happy, not Doc", the striking out of the three giving birth to the second string. This complicated language structuring tactic is what Bakhtin identifies as one of the two forms of hybridity wherein the politicization of language takes place: organic and intentional hybridity. These multisyllabic words are a moment in the latter. They are "inevitably internally dialogic $[\ldots]$ The "points of view are not mixed, but set against each other dialogically" [...] in this dialogized view of hybridity, different voices are pitted against each other, and each has the potential to unmask the other" (Sanga, 84).

\section{Ideals of Punctuationlessness}

Punctuationlessness in syntactic ordering is another means through which Rushdie conforms, paradoxically though, with the norm of arbitrariness earlier referred to. Realist code of arbitrariness may probably not anticipate Rushdie's over-enthusiastic realization of this language feature simply because realism, in most cases, deals with superficies and not the depths of speech creation by people. In a psycholinguistic manner, Rushdie forms sentences to explain the psychological state of characters, especially those whose consciousness is totally or partly impaired. A good case is Snow White who has just been discussed. Describing dead Belle, Snow White says "[...] she fooled with half of the town, rich man poor man beggar man thief" (Rushdie, 1994: 67) (Emphasis mine). It is clear that the comma rule in the italicized portion is flouted, as is the case in the first discussion on Snow White, decidedly to evidence the argument that Snow White is talking from her subconscious.

Rushdie, in the spirit of colloquialism, goes beyond this infraction against the comma rule to create single words from many words like "ifisaysomyself" (if I say so myself) (Rushdie, 1988: 183), "strangebuttrue" (strange but true) (245), "getoutofitsillyoldmoo" (get out of it silly old moo), "itsthesoddingbeach" (it's the sodding beach) (134), "whowhatwhy" (105) (who what why), "redwhiteblue" (red white blue) (6), "salvationdamnation" (salvation damnation) (92), "Allahgod" (Allah god) (92) "whatsitsname" (what's its name) (Rushdie, 2000: 41), "Whatdoyoumeanhowcanyousaythat" (what do you mean how can you say that) (260) and "dirtyfilthy" (dirty filthy) (Rushdie, 1994: 9). The "ifisaysomyself" word issues from Pamela, one of the migrants, to immediately assert her 
independence while relaying the information that she works in a community relations council, pointing out that she is "deputy community relations officer and damn good at it, ifisaysomyself" (183) (Emphasis mine). Pamela also uses the word (ifisaysomyself) to remotely show her disappointment at her British hosts' attitude to their migrant-guests. This is against the backdrop of the ill-treatment of the migrants in Britain's socio-political space. The instances of maltreatment are better understood in her words:

We just elected our first black Chair and all the votes cast against him were white [...]. Last week a respected Asian street trader, for whom MPs of all parties had interceded, was deported after eighteen years in Britain because, fifteen years ago, he posted a certain form forty-eight hours late [...]. Next week in Brickhall Magistrates' Court the police will be trying to fit up a fifty-year-old Nigerian woman, accusing her of assault, having previously beaten her senseless (Rushdie, 1988: 183).

The "getoutofitsillyoldmoo" and "itsthesoddingbeach" unconventional word formations Rosa Diamond ironically employs to attack what she sees as the feral behaviour of those who infringe on her own part of the beach where her house is located. The "beach" aspect of "itsthesoddingbeach" is, therefore, important and needs to be explained. "Sodding beach" is a reference to the grassy part of the beach, which she takes to be hers. However, the ambiguity becomes clear when one takes into account her anger and the animal content of her accusation in the noise made by a cow ("moo") in "getoutofitsillyoldmoo". In which case, "sodding beach" may even be "sodden bitch", meaning "a senseless female dog". Ironically, Rosa is also behaviourally located in that beastly tableau. That behaviour is explicit in "she descended upon them like a wolf on the fold" (Emphasis in the original). She is thus construed to be ferae naturae - wild by nature. Her negative characterisation stems from her being dismissive of the spiritual connotation of the word "ghost". It is indeed unsurprising that Gibreel implores her to "Rise ' $n$ ' shine! Let's take this place by storm" (Rushdie, 1988: 131).

Rosa's brutish presentation is ideologically understandably contrasted with Pamela's likable perception since the latter is an epitome of multiplicity, the thematic thrust of the novel; she being endowed with "a voice composed of tweeds, headscarves, summer pudding, hockey-sticks, thatched houses, saddle-soap, house-parties, nuns, family pews, large dogs, and philistinism" (180).

The "whowhatwhy" single-word questions can be taken to be a questioning of Mahound's monotheistic relevance in Jahilia's polytheistic environment. Hamza, his uncle, wonders at him appearing "dark" (1988: 105). Mahound responds by saying he has had a deal with Abu Simbel, an apostle of duality. It is thereupon in evidence that he (Mahound) has compromised "his terrifying singularity" (102). Gibreel's discomfort with "salvationdamnation" is his atheistic affront against an unqestioning belief in some tenets of Mahound's monotheism.

Punctuationlessness assumes a rather uncommon dimension when Saleem falls ill. Trapped in the throes of hysteria, his blabbing, the result of personality fragmentation, manifests in a no-comma, no-semicolon, no-colon sentence-filled page. (Rushdie, 2000: 238, 239) Only the period (.) punctuation sign is present. Such a drivel cannot be representative of a character who is compos mentis. Rushdie's freewheeling syntactic device is a realistic investigation of the innermost workings of a person, as distinct from the individual's outward manifestation, the concern of realists' character appreciation.

\section{Syntactic Creativity}

Rushdie's syntactic manipulation acquires some strangeness when he mixes exclamatives and probably Indian expletives to form phrases. Some are "wah, wah applause" (Rushdie, 1988: 91), "our ah researchers" (267), "Not to be confused ah ah with any magic carpet" (108) and "children mmff" (Rushdie, 2000: 485). (Emphasis in the last sentence mine) At times, he violates plural and adverbial rules to deautomatize the conventional meaning of some words. Few examples are: "misfortunately" (Rushdie, 1988: 56) and "unfortunates" (Rushdie, 2000: 470). Rushdie does not spare orthography in his resolve to undermine linguistic orthodoxy. In The Satanic Verses, instead of the word "simultaneous", he prefers “sy-multaneous" (11) to describe Gibreel's artistic plurality. The word "enormous" also changes to "enormouse" (91) to establish the celerity with which Gibreel moves from one place to the other simultaneously to perpetuate his conceptual multiform characterisation. Interpreted in the wider coloniser-colonised ambience, the suffix "mouse", literally expounded, refers to the colonised personality, who has been caught in the cultural snare of the colonizer. However, a grander literal perception reveals an indictment of the colonizers, who should have been the "mouse" by the fact of their invading other people's territory, and ought to have been caught in 
the bait of their hosts. Unnaturally, their (colonisers') invasion is with impunity. The "mouse" part of "enormouse" reflects a role reversal as Gibreel (a postcolonial character) makes forays into the "centre" and is indeed immune from reprisals. Antonyms also fall under Rushdie's language recreative focus. To him, the word "lefteous" (Rushdie, 1994: $295)$ is the immediate contrastive form of "righteous". This contrastive analysis has ideological undertones. It elucidates the doctrinaire position of the author in the left-right political divide, his leftist sentiments contributing functionally to the structure of the novel. The context in which the "lefteous"-"righteous" issue comes up clarifies Rushdie's leftist proclivity. In the employ of Mainduck, Moor listens to this ideological sloganeering from his boss: "We shall defeat the Scar-Zogoiby axis, whatever the cost [...] are you for us or against us, will you be righteous or lefteous? Say: are you with us or without?" Moraes decides to be "lefteous"; he is rebellious to the Anti-Zogoiby cause of Fielding and he is dismissed.

Rushdie indeed, in his creative capacity to manufacture words, uses word formation, through Saleem Sinai, the narrator in Midnight's Children, to reveal Sabarmati's wife's philandering. Saleem does this by cutting pieces out of newspapers and extracting morphemes like "COM", "MAN" "DER" et al out of the headlines to create the following revelation:

COMMANDER SABARMATI (my note read)

WHY DOES YOUR WIFE GO TO COLABA

CAUSEWAY ON SUNDAY MORNING? (Rushdie, 2000: 297, 298)

Rushdie's atheism comes alive when he plays on the American pronunciation of God. He comes up with "Guard Almighty [...] Oh, almighty guard" (Rushdie, 1988: 75). A bilingual that he is, or a polyglot that he may be, Rushdie exploits the opportunistic platform of code-shifting and code-mixing to mesmerise his readers. Here is an example of the former: "After all, "les acteurs ne sont pas des (the actors are not people) as the great Ham Frederick had explained in Les Enfants du Paradis" (Children of Paradise) (34). The following is an excerpted instance of the latter: "I long for them sometimes, in Rosa's practised thoughts. Le beaux jours: the dear, dead days" (130). The French phrase Le beaux jours means "the beautiful days". Another instance of code-mixing is "Now what is left for our Tavleen bibi? Zero. Story funtoosh" (81) (Emphasis mine). "Funtoosh", an Urdu or Hindi word, means "end"; Story funtoosh, therefore, means "end of story". There is also "the halal portion" (Rushdie, 2000: 62). In this case, a non-English adjectival is used to function as a qualifier to an English word. Halal is an Arabic word for lawful or legal or what is permissible to use or engage in. The "halal portion" in this context refers to the part of an animal that can be eaten. "Halal" is the opposite of "haram" in the Islamic linguistic world. The latter means that which is prohibited, unlawful or not fit and proper for Muslims to eat. The Indian author, in line with translinguistic dictates, does create adjectives by combining Indian and English words, the Indian variant occupying the head position, as in "dupatta-less" (64). The word "dupatta" is a large scarf that is "used to cover the head and is a mark of propriety" (http://www.subir.com/rushdie/glossary.html). "Dupatta-less" therefrom refers to dressing without scarf.

\section{Mythical and Scatological Wording}

Besides the insertion of myth-related words and phrases like "Hamsa" (Rushdie, 2000: 254), "Parahmsa" (254), "Padma" (223), "Brahma" (223), "Vishnu" (223), "Lord Khusrovand" (306), "Bhimutha" (306), "Devi" (467), "Mahisha" (467), "myth of Ramram Seth" (188), "Nandi" (Rushdie, 1994: 242), and "Mumbadevi" (294),etc., to propagate the esoteric function of their literary concern, Rushdie, true to the satirical-cum-comic portrayal of his protest initiative, employs scatological images to express his dissent from some deplorable social conditions. Indira Ghandi's vasectomists are called "Labia-lips" (Rushdie, 2000: 458), (a word connected with the female private organ). One of them (vasectomists) is said to have the "breath of bullock dung" (458) and the face of a "plump calf" (458). This is besides his having "unleashed a typhoon of halitosis" (458). The author calls both India and Pakistan "the sub-continent's lunatics" (Rushdie, 1994:173) chiefly because of the internecine battles between them, especially in relation to their fundamentalist religious beliefs. He uses the phrase "trinity of scum" (Rushdie, 1988: 101) to describe three unthinking and slavish citizens of Jahilia.

Mainduck, in The Moor's Last Sigh, is predictably not spared the author's scathing verbal whiplash. He (Mainduck) earns the following disparaging epithets from him: "this gutter-creature" (257), "the communalist toad" (257), "That bhaenchod" (256) and "this walking slum" (257). One of his henchmen, Chhaggan Five-in-a-Bite, cuts "an incongruously dishevelled and canteen-medalled scarecrow figure" (296). This member of his murderous squad is conceived of mainly in criminal and funereal terms as "a snaggletoothed giant who looked as if he were carrying an 
overcrowded cemetery inside his enormous mouth" (296). Vasco Miranda is "the fat fraud" (257) in Rushdie's moral estimation. The character is blamed by the "old guard" (326) of Benengeli for the presence of "expatriate vermin and [...] flotsam-jetsam of the earth" in the city (327). Abraham Zogoiby is seen as a "ruthless skeleton" (330).

\section{Terror-inspiring Wordage}

Since Rushdie revels in exploring tragi-comedy or dark comedy, the corpus into which most of his novels fall, he injects into their plot tragic and fear-inducing diction. The terrifying experiences of "Ayooba Shaheed Farooq" (Rushdie, 2000: 414) and the bhudda in the Sundarbans produce an awe-inspiring style. As the jungle grew in "size and ferocity" (415) and the forests closed "behind them like a tomb" (415), the quartet realized that "they were already beginning to succumb to the logic of the jungle" (415), which could only be dreadful. With the "sepulchral greenness of the forest" (415) and "anonymity of rain-forests" (414) taking total control of their intrusion "into the thraldom of that livid green world" (417), the four boy-soldiers have no choice but to surrender "themselves to the terrible phantasms of the dream-forest" (417). They are so subdued that they become a subject in Jungian psychoanalysis, falling into "the turbid, miasmic state of mind" (417) and "unable to distinguish between chasing-after and running-from" (414). Again, all these expressions parallel Okri's "pullulating darkness", (Okri, 1994: 25), "darkness kept opening and shutting (27), "the darkness was a solid space" (42), "shadows were changing places" (56), "haunting threnody" (70), "the dreams of the road became frightening" (70), "silver wings sliced open the heavens" (27), "night ate up the brief illumination" (43), "sepulchral voice" (Okri, 1995: 97) and "the darkness around [...] had grown massive" (110). The presence of animal skins, preternatural feathers, flywhisks, empty bed cages and spears, and the head of an antelope on walls (1995: 55), and even "of a room potent with ritual smells" (56) brings to bear on the plot the ritualistic culture and environment that inspire Okri.

\section{Animistic Verbalism}

Rushdie exploits the most incisive trope that most vividly captures the mysterious essence of fantasia creativity: personification but sparsely when compared with some other writers. However, in The Satanic Verses, there is a prodigious number of them. There is particularly the talking rat appearance in Minnie's vision for socially corrective ends (Rushdie, 1988: 239); "The knives [also] began to sing" (Rushdie, 2000: 48) during the murder of "the Hummingbird" (48). The writer, withal, makes us believe that "Midnight has many children" in Midnight's Children (333). The following are distilled from The Satanic Verses, and they are not exhaustive: "speed [...] whistling its fearful notes" (Rushdie, 1988: 8); "Gibreel's energy illuminated the gloom" (18); "shadows moving" (18); "if inaccuracies had crept into her versions [...]" (22); "nervy smile" (39); "insomniac nights" (24); "buffet table groaning" (29); "[...] his unspoken words demanded, why must I die [...]" (30); "lazy vowels" (33); and "roof of cloud fled upwards" (8).

Ben Okri, who is also embedded in fantastic writing, seems to be more forthcoming in the use of animistic wording than Rushdie. In Okri's mythopoesy, as amply demonstrated in The Famished Road and Songs of Enchantment, one is made to hear "the air whispering, walls talking, chairs complaining, floor pacing, insects gossiping". (Okri, 1992: 21) In his mythic world, "soup talks and hisses" (102), "The wind started" (297); "trees protesting" (297); "forests dream" (Okri, 1994: 24); "the forest sighs" (41); "wind whispers" (24); "wind sighs" (43); "shadows whisper" (84); "shadows dance" (29); "shadows stormed past" (11); "The road woke up" (9); "flowers bathed" (Okri, 1995: 11); "touched by a breeze" (119), "the wind murmured" (122); "Invisibility had conquered his mind" (128); they are legion in number and grand in scope, all denizens of the author's enchanting universe, where, he posits, "animistic clashing of machetes" (68) is substantially the rule.

\section{The Migrant's Diction of Fury}

The migrant's frustration at being subordinated to the caprices of the prosperous host and the desire to mutate so as to be accepted by the former colonial master is a compulsive feature in Rushdie's psychological penetration of the immigrant's use of language. Like the "flying" Gibreel, Pinkwala, "an Indian who has never seen India, East-India-man from the West Indies, white black man", (292) is contesting the English sole proprietary grip on the London locale. Unlike the protagonist, he can only do so by "diving", "abruptly" to an "underground", which has an "unmarked door", (291) where, exasperated, he is made to intrude into the third-person narrative process - maybe an expression of his disgust - to lampoon England: 
The migrants of the past, as much the living dancers' ancestors as their own flesh and blood, gyrate stilly while Pinkwala rants toasts raps up on stage, Now-me-feel-indignation-wen-dem-talk-immigration-when-them-make-insinuatio n-we-no-part-a-de-nation-an-me-make-proclamation-a-de-true-situation-how-we -make-contribution-since-de-Rome-Occupation. (292)

The causerie or informal aspect of the quotation above is Pinkwala's loaded verbal fight-back at his "lapsed" master. The rhyme presence of "indignation", "immigration", "insinuation", "nation", "proclamation", "situation", "contribution" and "occupation" sums up the psycho-lingual torture that makes the coloniser the butt of the colonised's accusation of being unappreciative of their involvement in the affluence of England. It corroborates the opinion that "once the imperial interchange is set in motion, fiction between nations illuminates fiction between nations-in-a-nation" (Brennan, 1989: 41) not minding the fact that "the traveller feels at home everywhere, because she is never at home anywhere" (39); as such, "migrants remain the primal translated and translating beings" (quoted in Ghosh, 136).

\section{Paradoxical Expressions}

Paradoxes, as a linguistic strategy, dominate the thinking of the postcolony. Rushdie, though does not deploy paradoxical phrases prodigiously, conceives many of his works in paradoxes to idealize notions of duality. Many of the characters in The Moor's Last Sigh, i.e, Aurora, Abraham and Uma ventilate their contentions through the contradictions in paradoxes. In spite of this paucity of these paradoxical wording, one can identify the clause "millionaire flirting with Marxism" (Rushdie, 1994:32) to describe Camoen's ideological vacillation. A "confused fool of a boy" (32), he calls him. In describing Pakistan, a city that Saleem loves to hate, he leans on the tropological finesse of two contradiction-inspired figures of speech: irony and oxymoron. While "barren certitudes of the land of the pure" (Rushdie, 2000:362) ironically portrays the country, "a gigantic dwarf" (352) is the realization of its oxymoronic depiction. Although there are more instances of paradoxical use of language in Okri's works than those of Rushdie, there is no understating the presence of a very gripping paradoxical statement in the latter's The Satanic Verses: Gibreel admitting that he says and unsays almost immediately (123), the action being a consummate explanation of the conflict-driven oral refrain that the author refers to in the novel when telling his stories: "it was so and it was not so" $(35,37)$. Jacques Derrida calls this writing under erasure.

Okri's exuberant use of paradoxes is the especial concern in Astonishing the Gods, the main idea of which is paradoxical, as the visitor who leaves his town to search for the secrets of visibility, ends up with the acquisition of the "invisibility of the blessed" (159), a sublime invisibility. On the island, the lighter a substance becomes, the heavier it is. The visitor acknowledges this when he comes under the gaze of the ArchAngel, and his weighty essence is completely destroyed (39). The post-structuralist re-defining of the functions of banks, hospitals and courts in the dream world also concretizes the play on paradoxes.

Probably the most functional of the ironies on the island is the vision of "beautiful things flowering from great suffering" (142), the stress on "transcendental suffering" as a prerequisite for spiritual, political and socio-cultural salvation, and the awareness that the great civilisation on the island is wrought by geniuses who have spent five hundred years of "self-disintegration" beneath the sea (29). Suffering is said to exist in the beauty of everything on the island. Everything, the visitor is told, is guided by the wisdom of suffering. "The simplest things", he is informed by the dwarf-like creature, "are riddles and paradoxes" (105). The "season's fashion was for paradoxes, and the market place, even at night, was abuzz with fresh-minted paradoxes and ancient riddles from the farthest corners of the world" (74). That is why when the visitor is with the youth-guide, he sees the city's lights concealed in darkness and hears the city's silences. The smaller he feels the greater he becomes.

The Famished Road in some instances also exemplifies these philosophical thoughts on paradoxes in Ade falling in love with being "free in the captivity of freedom", Azaro preferring the "liberty of limitations", king of spirits "speaking in silence" and a woman covered in "golden boils". (Okri, 1992: 200) A fetid paradox also exists in the Party of the Rich's campaign promise: "Vote for us. We are the party of the rich, friends of the poor" (123). An old man has a face that is "ugly with joy" (287). Another man also has a "lively face and sad eyes" (292). Witches and wizards "brought an almost sweet smell of evil" (416) to see what Black Tyger looked like after his defeat of Green Leopard.

\section{Interdisciplinary Linguistic Dissemination}

Salman Rushdie seems to be more prominent in crossing disciplinary lines than many postcolonial writers as regards word-stock. The Satanic Verses is seminally and particularly rooted in multidimesionality; a shade of its 
language use is, therefore, understood in vocational conversational dissemination. It encompasses a farrago of theological, geographical and scientific idioms. The allusions: "To be born again [...]" (3) and "[...] they had walked upon the water [...]" (11) apparently relate to Christianity. These are besides the many instances of Islam-related statements. This is not unexpected since the work's multifocal angst is in part against fundamentalist monotheism of Muhammedanism. "Reincarnation", understood in its literal application, is itself the diction in theological ideologising. The atmospheric locus from where Gibreel and Chamcha plummet is said to be encased in cloudy forms of "cumulus" and "cumulo-nimbus" (Rushdie, 1988: 5). The profuse discourse on expeditionary campaigns to Mount Everest, the survival analysis that trails the successful climb to its summit by some characters, despite defying scientific requisite steps, and the references to "sleeve" and "Himalayan height" are intimations of geographical science in the novel's languaging. There are also few instances of incursion into the biological sciences like the dropping of "genitalia", and the allusion to Charles Darwin's "The Origin of Species" (251) to substantiate mutative realities.

\section{Symbolic Lingual Representations}

As an avant-garde member of the contemporary postmodernist school, Rushdie is wont to project his characters in symbolic and metaphorical terms. Symbolic representations manifest in literary items and characters, especially as they concern the distinction between the European culture and the traditional Indian way of life. Quite distinctive is the symbolic relevance of snakes and ladders. Although a game of rewards and penalties (160), it is an appropriate epitome of the hierarchical structure of the West, which the ladder stands for, and the ambivalence-prone sentiment of the post-colonial writer, which is idealized in the winding movement of snakes. Beyond this dual symbolic expression, the ambivalence of multiculturalism and the undercutting edge of deconstruction are openly pronounced in the realization that for every ladder one climbs, a snake is lurking around the corner, and that for every snake, a ladder will duly compensate. The ladder itself, also analysed independently, can be identified with the hybrid culture of the protest tradition as it can go down as well as up. This ambiguity is also represented in the paradox of the venom of cobra snake offered for the cure of Baby Saleem when he is ill.

Another protest symbol is the unstained perforated sheet that stands between Aadam Aziz, a doctor and Saleem's grandfather, and Naseem, the daughter of Mr. Ghani. Aadam Aziz's cultural vision having been altered by a West-inspired education, as shown in his propagation of the ideologies of German thinkers like Heidelberg and Ingrid, he finds it difficult to reconnect himself with his traditional root until he is called upon to treat Naseem. As a matter of principle, Mr. Ghani does not allow "strangers" to see the face of his daughter and, therefore, places a perforated curtain, a sort of wedge between the doctor Aadam and the patient Naseem. In symbolic reasoning, the curtain may stand for a separation from the ideals of one's culture, and for Aadam Aziz, the German-trained doctor, to breach it, he would have to align his foreign consciousness with his cultural past. This he does since he desires Naseem as wife. That some characters, including the narrator, symbolize some ideals is not in doubt, but Brass Monkey, Saleem's sister, is an interesting protest affair for she is convinced, according to the narrator, that "if she was going to get any attention, she would have to make plenty of noise" (169). This conviction reasons her into destroying shoes and ultimately she becomes a famous singer in Pakistan, which enables her "to make plenty of noise" (169). Strong postmodern symbolic conviction comes to the fore in the spatial antithesis between Bombay city in India and Karachi in Pakistan. The narrator is piqued, even in his diction, at the monotonous reality that one is forced to submit to in Karachi, being a mono-religious and mono-cultural land. The vitriolic language with which he describes the city is doubtlessly not unexpected. The narrator feels "tethered to a stake" in his observation that the city is

full of deformed houses, the stunted hunchback children of deficient lifelines, houses growing mysteriously blind, with no visible windows, houses which looked like radios or air-conditioners or jail-cells, crazy top-heavy edificies, which fell over with monotonous regularity, like drunks; a wild proliferation of mad houses, whose inadequacies as living quarters were exceeded only by their quite exceptional ugliness. The city obscured the desert; but either the cords, or the infertility of the soil, made it grow into something grotesque. (354). (Emphasis mine)

Bombay and Karachi are two cities that define the identity of the narrator. Both represent disparate sensibilities for him. By extension, the Bombay-Karachi dichotomy is symbolic of the positivity in heterogeneity and negativity in homogeneity. Saleem prefers "the highly-spiced nonconformity of Bombay" (353), which he "saw as teeming, as manifold, as multitudinously shapeless as ever" (143) to the "misshapen lumpiness of a gigantic dwarf" (352) called Karachi, whose citizens "had only the slipperiest grasp on reality, and were, therefore, willing to turn to their leaders 
for advice on what was real and what was not" (353). He confesses that he "never forgave Karachi for not being Bombay" (352). He feels disgusted to be

in a country where the truth is what it is instructed to be, [where] reality quite ceases to exist, so that everything becomes possible except what we are told is the case; and maybe this was the difference between my Indian childhood and Pakistani adolescence - that in the first I was beset by an infinity of alternative realities, while in the second I was adrift, disorientated, amid an equally infinite number of falsenesses, unrealities and lies. (373) (Emphasis mine)

Saleem, showing his ire at "Euramerican" proclivity towards an inflexible understanding of truth and other apostles of various orthodoxies, veritably concludes that "Nobody, no country, has a monopoly of untruth" (373). Symbolisation in The Satanic Verses revolves mainly round Gibreel simply because he embodies literally and literarily almost all the other characters in his seeking after multiplicity. The air and dream loci, the London locus as well, all typify Gibreel's mutation obsession. Jahilia, where Mahound wants to plant his terrifying singularity, is, unknown to him, deeply rooted in plurality.

\section{Conclusion}

Language, being the substructure of any culture, veritably becomes the battleground between the colonizer and the colonized, the longing for control of which announces a war of attrition between the two antagonists. Rushdie is not oblivious of the colonizer-strength as far as the question of who has a more overriding mastery of the language locus is concerned. He tries to mitigate the damage to the ego of the postcolony. In some ways, he seems to succeed. However, in the final analysis, his efforts may not go beyond moments of tropological outpouring, for the spectral influence of the English language as a uniting force in most postcolonial societies may be an inhibiting factor in the author's craving for a comprehensive overhaul. This inertia has not, however, stopped him and other postcolonial authors from succeeding in creating some heteroglossic newness, after all, "it was in the novel that previously foreign languages met each other on the same terrain, forming an unsettled mixture of ideas and styles [...]" (Brennan, 9), a literary situation through which "the world becomes polyglot, once and for all and irreversibly" (quoted in Brennan, 9). Doubtlessly, "the syncretic and hybridized nature of postcolonial experience refutes the privileged position of a standard code in the language and any monocentric view of human experience" (quoted in Ball, 24).

\section{References}

Ball. J.C. (2003). Satire and the postcolonial novel. New York: Routledge.

Banerjee, Mita. (2002). The chutneyfication of history. C.Winter: Universitätsverlag.

Booker, M. Keith. (1994). Beauty and the beast: Dualism as despotism in the fiction of Salman Rushdie. In D.M. Fletcher (Ed.), Reading Rushdie: Perspectives on the fiction of Salman Rushdie. Amsterdam: Rodopi.

Booker, M. Keith. (1999). Salman Rushdie: The development of a literary reputation. In Booker, M. Keith (Ed.), Critical essays on Salman Rushdie. New York, NY: G. K. Hall \& Co.

Brennan, Timothy. (1989). Salman Rushdie and the third world. New York, NY: St. Martins Press.

Fanon, Frantz. (1967). Black skin, white masks. Broadway: Grove Press.

Fletcher, M.D. (1994). The politics of Salman Rushdie's fiction. In Fletcher, D.M (Ed.), Reading Rushdie: perspectives on the fiction of Salman Rushdie. Amsterdam: Rodopi.

Ghosh, Bishnupriya. (1999). An invitation to Indian postmodernity: Rushdie's English vernacular as situated cultural hybridity. In Booker, M. Keith (Ed.), Critical essays on Salman Rushdie. New York: G. K. Hall \& Co.

Hirschkop. K., \& Shepherd. D. (Eds). (1994). Bakhtin and cultural theory. Manchester: Manchester University Press.

Okri, Ben. (1992). The Famished road. London: Vintage Books Ltd.

(1994). Songs of enchantment. London: Vintage Books Ltd.

(1995). Astonishing the gods. London: Phoenix House.

Reder, Michael. (ed.). (2000). Conversations with Salman Rushdie. Jackson: University Press of Mississipi.

Rushdie, Salman. (1988). The Satanic verses. Delaware: The Consortium, Inc. 
. (1994). The Moor's last sigh. London: Vintage Books Ltd.

. (2000). Midnight's children. New York, NY: Penguin Books Ltd.

. Glossary to accompany Salman Rushdie. (2011, January 13). Retrieved from http://www.subir.com/rushdie/glossary.html).

Sanga, J.C. (2001). Salman Rushdie's postcolonial metaphors. London: Greenwood Press.

Soyinka, Wole. (1993). Art, dialogue and outrage. New York, NY: Pantheon Books.

The Rushdie Affair. (2002, November 27). First mounted August 18, 1996. Last revised June 14, 2002. In "Notes for Salman Rushdie: The Satanic Verses". Retrieved from (file:// A:INotes for Salman Rushdie The Satanic Verses).

Wallia, C.J.S. (2002). The Rushdie phenomenon: A second look. (2002, April 23). Retrieved from http://www.indiastar.com/rsighs.htm (Pp.2, 3, 4, 5\&7) 